\title{
In-vitro GLP-1 Release Assay Using STC-1 Cells
}

Liu Qi' ${ }^{1}$ Tan Shuai ${ }^{1}$, Jia Da², Burstein Ezra ${ }^{1}$ and Sifuentes-Dominguez Luis ${ }^{3}$ *

\begin{abstract}
${ }^{1}$ Department of Internal Medicine, Division of Digestive and Liver Diseases, University of Texas Southwestern Medical Center, Dallas, United States; ${ }^{2}$ Key Laboratory of Birth Defects and Related Diseases of Women and Children, Department of Pediatrics West China Second University Hospital, State Key Laboratory of Biotherapy and Collaborative Innovation Center of Biotherapy, Sichuan University, Chengdu, China; ${ }^{3}$ Department of Pediatrics, Division of Pediatric Gastroenterology, Hepatology and Nutrition, University of Texas Southwestern Medical Center, Dallas, United States *For correspondence: Luis.Sifuentes-Dominguez@UTSouthwestern.edu
\end{abstract}

[Abstract] Enteroendocrine cells (EECs) are known chemosensors in the gastrointestinal (GI) epithelium. They release a diversity of gut hormones in response to various stimuli. Here, we report an in-vitro assay to measure GLP-1 release from cultured murine EEC's under fatty acid stimulation.

Keywords: Enteroendocrine cells, L-cells, STC-1, Docosahexaenoic acid (DHA), Glucagon-like peptide-1 (GLP-1)

[Background] The intestinal epithelium is the largest interface between the human body and the environment. This interface consists of a single epithelial layer containing several distinct cell-types with unique functional roles. Differentiated from LGR5-positive epithelial stem cells, enteroendocrine cells (EECs) are scattered throughout the epithelium along the entire GI tract. EECs play a critical role in responses to nutrient and other stimuli by producing and secreting a variety of hormones. Traditionally, these cells are classified by their hormonal profile (Nausheen et al., 2013; Latorre et al., 2016; Verhoeckx et al., 2015a), although with the advent of single cell RNA-sequencing, we have come to appreciate that most of these cells secrete multiple hormones (Haber et al., 2017; Billing et al., 2019). A subtype of EECs, L-cells, are defined by the production of glucagon-like peptides 1 and 2 (GLP-1 and GLP-2), and may also secrete peptide YY (PYY) and insulin-like peptide 5 (INSL5). Most L-cells are found in the distal ileum and colon, while some are also found proximally in the duodenum and jejunum. The receptors on the surface of L-cells allow them to directly sense luminal components and produce appropriate hormone responses. The most notable receptors of nutrients and food components on Lcells are the classic taste receptors, free fatty acid receptors and receptors for protein and their products (Drucker and Nauck, 2006; Furness et al., 2013; Spreckley and Murphy, 2015; Gribble and Reimann, 2016; Parada Venegas et al., 2019). L-cells can also sense LPS through expressing Toll-like receptors (TLRs) (Lebrun et al., 2017). By producing hormones, L-cells are able to stimulate carbohydrate uptake and insulin release, slow down intestinal transit and regulate appetite.

To study the role of $L$ cells in-vitro, numerous human and rodent mouse cell lines have been derived. The $\mathrm{NCl}-\mathrm{H} 716$ cell line, the only human EEC line, was derived from a spontaneous colorectal tumor. The NCl-H716 cell line produces GLP-1, PYY and mucin and is thought to represent distal L-cells. They 
require a basement membrane to attach to culture plates and only $30 \%$ of $\mathrm{NCl}-\mathrm{H} 716$ cells produce $\mathrm{PYY}$, thus limiting their use in routine in-vitro experiments (Park et al., 1987; Verhoeckx et al., 2015b). To overcome the limitations posed by this cell line, non-human EECs have been derived. Notably, GLUTag and STC-1 are of great utility in the study of GLP-1 secretion. The GLUTag cell line is a single-cell subcloned population of L-cells, established from a large bowel tumor in proglucagon-SV40 Large T antigen transgenic mice. They are easy to transfect and secrete GLP-1 and CCK. Like the NIC-H716 cells, GLUTag cells also need attachment matrices (Chang et al., 1994; Drucker et al., 1994; Verhoeckx et al., 2015b). In contrast to GLUTag cells, the STC-1 cell line was established from a secretin producing tumor, which arose in the duodenum of double transgenic mice expressing proinsulin-SV40 Large T antigen/proinsulin-polyoma x Small T antigen. Like native intestinal L-cells, STC-1 cells produce GLP1, CCK, GIP, PYY, pancreatic polypeptide, neurotensin, GLP-2 and oxyntomodulin, in varying amounts (Rindi et al., 1990; Verhoeckx et al., 2015b). They are easy to culture without the need for an attachment matrix. These features make STC-1 cells a good model to study hormonal secretion mechanisms.

Like EECs of the large intestine, STC-1 cells harbor a variety of nutrient receptors. Prior work has demonstrated that various substances binding to specific cell-surface receptors on STC-1 cells results in hormone secretion (McCarthy et al., 2015). Notably, fatty acids elicit strong CCK secretion from STC1 cells, thus they have been extensively used to study CCK secretion dynamics. However, few studies have focused on fatty acid induced GLP-1 secretion or have failed to address variation in cellular density (McLaughlin et al., 1998; Sidhu et al., 2000; Benson et al., 2002; Hirasawa et al., 2005). Here we describe a method to measure GLP-1 secretion from STC-1 cells upon fatty acid stimulation.

\section{Materials and Reagents}

1. $10 \mathrm{ml}$ Glass bottles

2. $50 \mathrm{ml}$ Glass beaker

3. $5 \mathrm{ml}$ Glass pipettes (Corning, catalog number: 7077-5N)

4. Capillary Micropipettes (Drummond Scientific Company, catalog number: 5-000-2005)

5. 6-cm dishes (Corning, catalog number:430166)

6. $10 \mathrm{ml}$ and $50 \mathrm{ml}$ sterile plastic pipettes with filter (Corning, catalog numbers: 4488,4490 )

7. Sterile cell lifts (Corning, catalog number: 3008 )

8. $1.5 \mathrm{ml}$ microcentrifuge tubes (Fisherbrand, catalog number: 05-408-129)

9. $1.5 \mathrm{ml}$ disposable cuvettes (BRAND, catalog number: 759076D)

10. STC-1 cell line (ATCC, catalog number: CRL-3254 ${ }^{\mathrm{TM}}$ )

11. Phosphate-buffered saline (Sigma, catalog number: D8537)

12. Trypsin (Corning, catalog number: $25-053-\mathrm{Cl}$ )

13. DMEM, High Glucose (Hyclone, catalog number: SH30022.02)

14. Fetal Bovine Serum (Gibco, catalog number: 35050-061)

15. Enrofloxacin (Sigma, catalog number: 17849-5G-F)

16. Docosahexaenoic acid, DHA (Nu-chek-policy, U-84-A DHA, 1GM), DHA comes as a solution 
17. Pure ethanol (Pharmco Products, catalog number: $111000200 \mathrm{C} 1 \mathrm{GL}$ )

18. Nitrogen gas

19. HEPES (Sigma, catalog number: H3375)

20. $\mathrm{NaCl}$ (Fisher Scientific, catalog number: BP358-10)

21. $\mathrm{KCl}$ (Sigma, catalog number: P9333)

22. $\mathrm{CaCl}_{2}$ (Sigma, catalog number: $\mathrm{C} 1016$ )

23. $\mathrm{MgCl}_{2}$ (Sigma, catalog number: M8266)

24. EDTA (OmniPur, catalog number: 4050)

25. Triton X-100 (Fisher Scientific, catalog number: BP151-500)

26. Tris-base (Fisher Scientific, catalog number: BP152-5)

27. PMSF (MP biomedicals, catalog number: 195381)

28. Halt ${ }^{\mathrm{TM}}$ Protease and Phosphatase Inhibitor Cocktail (100x) (Thermo Fisher Scientific, catalog number: 78444)

29. Sterile water

30. Protein assay dye reagent concentrate (Bio-Rad, catalog number: 5000006)

31. High sensitive glugagon-like peptide(GLP-1) active chemiluminescent ELISA kit (Millipore, catalog number: EZGLPHS-35K)

32. $10 \mathrm{mg} / \mathrm{ml}$ DHA stock solution (see Recipes)

33. HEPES buffer (see Recipes)

34. $100 \mu \mathrm{M}$ DHA Stimulation buffer (see Recipes)

35. Cell lysis buffer (see Recipes)

36. 100 mM PMSF stock solution (see Recipes)

\section{Equipment}

1. Portable Pipet-Aid ${ }^{\circledR}$ XP Pipette Controller (Drummond Scientific Company, catalog number: 4000-101)

2. Tissue culture incubator

3. Refrigerated microcentrifuge (Eppendorf, model: 5424R)

4. Sonicator (Branson 250 Sonifier)

5. ELISA plate reader (TECAN, Sunrise absorbance microplate reader)

\section{Procedure}

A. Prepare $10 \mathrm{mg} / \mathrm{ml}$ docosahexaenoic acid (DHA) stock solution (see Recipe)

1. Dilute DHA solution with pure ethanol at $10 \mathrm{mg} / \mathrm{ml}$.

Note: DHA will stick to plastic material. Always remember to use glass pipettes when you work with fatty acids.

2. Aliquot DHA stock solution into small glass bottles, $10 \mathrm{ml}$ each. 
3. Ambient air above the solution should be displaced to avoid oxidation of DHA by priming pure nitrogen gas on the surface of the solution prior to closing the container.

4. Store at $-20^{\circ} \mathrm{C}$.

B. DHA Stimulation assay

1. Seed $2 \times 10^{6}$ STC-1 cells in 6-cm dishes two days prior to experiment in duplicates. Culture the cells in tissue culture incubator at $37{ }^{\circ} \mathrm{C}, 5 \% \mathrm{CO}_{2}$, using DMEM with $10 \% \mathrm{FBS}$ and $20 \mathrm{ng} / \mathrm{ml}$ enrofloxacin.

2. On experimental day cells should be $80 \%$ confluent.

3. Aspirate media and wash the cells twice with $3 \mathrm{ml}$ of HEPES buffer.

4. Add $3 \mathrm{ml}$ of HEPES buffer into each dish.

5. Put cells back to tissue incubator for $30 \mathrm{~min}$. The lack of nutrients in the buffer is meant to serve as a 'starvation' period prior to nutrient stimulation.

6. Prepare $100 \mu \mathrm{M}$ DHA stimulation buffer.

a. To prepare $20 \mathrm{ml}$ of $100 \mu \mathrm{M}$ DHA stimulation buffer, add $66 \mu \mathrm{l}$ of $10 \mathrm{mg} / \mathrm{ml} \mathrm{DHA}(30.4 \mathrm{mM})$ stock solution into a glass beaker using glass capillary micropipettes. Then add $20 \mathrm{ml}$ of HEPES buffer.

b. Sonicate the solution immediately at output level 5 and constant duty cycle for 3 min prior to stimulation to prevent DHA precipitation. If using a different sonicator, set the amplitude as $40 \%$. After sonication, the solution should be clear, with minimal bubbling.

Note: Always prepare this DHA solution freshly, just prior to use.

7. Aspirate HEPES buffer gently. Then add $1 \mathrm{ml}$ of HEPES buffer into each control dish and $1 \mathrm{ml}$ of DHA stimulation buffer into each stimulation dish. Put all dishes back to tissue culture incubator for $15 \mathrm{~min}$.

8. Collect $600 \mu \mathrm{l}$ of media from each dish and put into a fresh $1.5 \mathrm{ml}$ microcentrifuge tube, then place them on ice.

9. Add $0.6 \mu \mathrm{l}$ of $100 \mathrm{mM}$ PMSF (see Recipe) into the $600 \mu \mathrm{l}$ of media at final concentration of $100 \mu \mathrm{M}$.

10. Spin the microcentrifuge tubes at $850 \times g$ for $5 \mathrm{~min}$, at $4{ }^{\circ} \mathrm{C}$.

11. Transfer $500 \mu \mathrm{l}$ of media into a fresh tube.

Note: Samples are now ready for ELISA measurement. One can also store samples at $-80{ }^{\circ} \mathrm{C}$ up to two weeks.

12. Measure GLP-1 concentration in samples by ELISA kit according to manufacturer's instructions. Make sure to set the standard as suggested by the manufacturer.

C. Lyse the cells in the culture and measure protein concentration from all dishes by Bradford assay Note: This is meant to account for differences in the number of cells in each dish in these experiments.

1. Carefully remove any residual HEPES buffer in each dish. 
2. Add $1 \mathrm{ml}$ of cold PBS into each dish.

3. Scrape cells down very carefully using a cell lift.

4. Collect cells into a $1.5 \mathrm{ml}$ microcentrifuge tube and put on ice.

5. Spin the tubes at $850 \times g$ for $5 \mathrm{~min}$, at $4{ }^{\circ} \mathrm{C}$.

6. Aspirate supernatants, then add $50 \mu \mathrm{l}$ of cell lysis buffer and pipette up and down gently to homogenize. Put tubes on ice.

7. Lyse the cells for $20 \mathrm{~min}$. Vortex every $5 \mathrm{~min}$.

8. Spin the tubes at $21,130 \times g$ for $15 \mathrm{~min}$, at $4{ }^{\circ} \mathrm{C}$.

9. Transfer supernatants into a fresh tube.

10. Measure protein concentration using protein assay dye reagent concentrate according to manufacturer's instructions.

\section{Data analysis}

Calculate measured GLP-1 concentration of each sample appropriately from three independent experiments, duplicates in each experiment. Then normalize the value to its corresponding protein concentration value as measured by Bradford assay (Table 1). Use any software package with 4parameter logistic regression for ELISA analysis.

Table 1. Adjusted GLP-1 concentration

\begin{tabular}{|l|l|c|l|l|l|}
\hline & Adjusted GLP-1 & Experiment & No FA (average GLP-1) & 54.63834 & \\
\hline No FA Parental & 56.75393031 & 1 & DHA (average GLP-1) & 492.2011 & \\
\hline No FA Parental & 55.23913626 & 2 & & & \\
\hline No FA Parental & 51.92193876 & 3 & & No FA & DHA \\
\hline DHA 100 Parental & 439.799523 & 1 & SD & 2.471388 & 137.8699 \\
\hline DHA 100 Parental & 388.2149664 & 2 & SEM & 1.426856 & 79.5992 \\
\hline DHA 100 Parental & 648.5889426 & 3 & P value & 0.005341 & \\
\hline
\end{tabular}

\section{Notes}

Using healthy cells is critical for experiments to work. One should check cell growth status and mycoplasma routinely. Always remember to fill DHA stock solution with nitrogen and prepare stimulation buffer fresh prior to use. If one freezes samples at $-80^{\circ} \mathrm{C}$, do not freeze and thaw repeatedly.

\section{$\underline{\text { Recipes }}$}

1. $10 \mathrm{mg} / \mathrm{ml} \mathrm{DHA} \mathrm{stock} \mathrm{solution}$

a. $600 \mu \mathrm{l}$ of DHA liquid coming from the manufacturer $(1 \mathrm{~g}, 1.2 \mathrm{ml}$ in total) 
b. $49.4 \mathrm{ml}$ of $100 \%$ pure ethanol

c. Aliquot into small glass bottles and fill with nitrogen gas. Store at $-20^{\circ} \mathrm{C}$

2. HEPES buffer

20 mM HEPES, pH 7.9

$140 \mathrm{mM} \mathrm{NaCl}$

$4.5 \mathrm{mM} \mathrm{KCl}$

$1.2 \mathrm{mM} \mathrm{CaCl}_{2}$

$1.2 \mathrm{mM} \mathrm{MgCl}_{2}$

3. $100 \mu \mathrm{M}$ DHA Stimulation buffer

$66 \mu \mathrm{l}$ of $10 \mathrm{mg} / \mathrm{ml}$ DHA stock solution

$20 \mathrm{ml}$ of HEPES buffer

Sonicate the solution at output level 5 constant duty cycle for 3 min prior to use

4. Cell lysis buffer

25 mM HEPES, pH 7.9

$100 \mathrm{mM} \mathrm{NaCl}$

1 mM EDTA

$10 \%$ Glycerol

$1 \%$ Triton X-100

5. $100 \mathrm{mM}$ PMSF stock solution

$174.2 \mathrm{mg}$ PMSF

$10 \mathrm{ml}$ of $100 \%$ ethanol

\section{Acknowledgements}

This work was made possible by funding to LS-D from the following sources: NIH 5 K12 HD-06836905 and Children's Health Clinical Research Advisory Committee: CCRAC 195.

This protocol was adapted from Hirasawa et al. (2005).

\section{Competing interests}

The authors declare no competing interests.

\section{$\underline{\text { References }}$}

1. Benson, R. S., Sidhu, S., Jones, M. N., Case, R. M. and Thompson, D. G. (2002). Fatty acid signalling in a mouse enteroendocrine cell line involves fatty acid aggregates rather than free fatty acids. J Physiol 538(Pt 1): 121-131.

2. Billing, L. J., Larraufie, P., Lewis, J., Leiter, A., Li, J., Lam, B., Yeo, G. S., Goldspink, D. A., Kay, R. G., Gribble, F. M. and Reimann, F. (2019). Single cell transcriptomic profiling of large 
intestinal enteroendocrine cells in mice - Identification of selective stimuli for insulin-like peptide5 and glucagon-like peptide-1 co-expressing cells. Mol Metab 29: 158-169.

3. Chang, C. H., Chey, W. Y., Sun, Q., Leiter, A. and Chang, T. M. (1994). Characterization of the release of cholecystokinin from a murine neuroendocrine tumor cell line, STC-1. Biochim Biophys Acta 1221(3): 339-347.

4. Drucker, D. J., Jin, T., Asa, S. L., Young, T. A. and Brubaker, P. L. (1994). Activation of proglucagon gene transcription by protein kinase-A in a novel mouse enteroendocrine cell line. Mol Endocrinol 8(12): 1646-1655.

5. Drucker, D. J. and Nauck, M. A. (2006). The incretin system: glucagon-like peptide-1 receptor agonists and dipeptidyl peptidase-4 inhibitors in type 2 diabetes. Lancet 368(9548): 1696-1705.

6. Furness, J. B., Rivera, L. R., Cho, H. J., Bravo, D. M. and Callaghan, B. (2013). The gut as a sensory organ. Nat Rev Gastroenterol Hepatol 10(12): 729-740.

7. Gribble, F. M. and Reimann, F. (2016). Enteroendocrine Cells: Chemosensors in the Intestinal Epithelium. Annu Rev Physiol 78: 277-299.

8. Haber, A. L., Biton, M., Rogel, N., Herbst, R. H., Shekhar, K., Smillie, C., Burgin, G., Delorey, T. M., Howitt, M. R., Katz, Y., Tirosh, I., Beyaz, S., Dionne, D., Zhang, M., Raychowdhury, R., Garrett, W. S., Rozenblatt-Rosen, O., Shi, H. N., Yilmaz, O., Xavier, R. J. and Regev, A. (2017). A single-cell survey of the small intestinal epithelium. Nature 551(7680): 333-339.

9. Hirasawa, A., Tsumaya, K., Awaji, T., Katsuma, S., Adachi, T., Yamada, M., Sugimoto, Y., Miyazaki, S. and Tsujimoto, G. (2005). Free fatty acids regulate gut incretin glucagon-like peptide-1 secretion through GPR120. Nat Med 11(1): 90-94.

10. Latorre, R., Sternini, C., De Giorgio, R. and Greenwood-Van Meerveld, B. (2016). Enteroendocrine cells: a review of their role in brain-gut communication. Neurogastroenterol Motil 28(5): 620-630.

11. Lebrun, L. J., Lenaerts, K., Kiers, D., Pais de Barros, J. P., Le Guern, N., Plesnik, J., Thomas, C., Bourgeois, T., Dejong, C. H. C., Kox, M., Hundscheid, I. H. R., Khan, N. A., Mandard, S., Deckert, V., Pickkers, P., Drucker, D. J., Lagrost, L. and Grober, J. (2017). Enteroendocrine L cells sense LPS after gut barrier injury to enhance GLP-1 secretion. Cell Rep 21(5): 1160-1168.

12. McCarthy, T., Green, B. D., Calderwood, D., Gillespie, A., Cryan, J. F. and Giblin, L. (2015). STC-1 Cells. In: Verhoeckx, K., Cotter, P., López-Expósito, I., Kleiveland, C., Lea, T., Mackie, A., Requena, T., Swiatecka, D. and Wichers, H. (Eds.). In: The Impact of Food Bioactives on Health. Springer, 211-220.

13. McLaughlin, J. T., Lomax, R. B., Hall, L., Dockray, G. J., Thompson, D. G. and Warhurst, G. (1998). Fatty acids stimulate cholecystokinin secretion via an acyl chain length-specific, $\mathrm{Ca}^{2+}$ dependent mechanism in the enteroendocrine cell line STC-1. J Physiol 513 (Pt 1): 11-18.

14. Nausheen, S., Shah, I. H., Pezeshki, A., Sigalet, D. L. and Chelikani, P. K. (2013). Effects of sleeve gastrectomy and ileal transposition, alone and in combination, on food intake, body weight, gut hormones, and glucose metabolism in rats. Am J Physiol Endocrinol Metab 305(4): E507-518. 
15. Parada Venegas, D., De la Fuente, M. K., Landskron, G., Gonzalez, M. J., Quera, R., Dijkstra, G., Harmsen, H. J. M., Faber, K. N. and Hermoso, M. A. (2019). Short chain fatty acids (SCFAs)mediated gut epithelial and immune regulation and its relevance for inflammatory bowel diseases. Front Immunol 10: 277.

16. Park, J. G., Kramer, B. S., Steinberg, S. M., Carmichael, J., Collins, J. M., Minna, J. D. and Gazdar, A. F. (1987). Chemosensitivity testing of human colorectal carcinoma cell lines using a tetrazolium-based colorimetric assay. Cancer Res 47(22): 5875-5879.

17. Rindi, G., Grant, S. G., Yiangou, Y., Ghatei, M. A., Bloom, S. R., Bautch, V. L., Solcia, E. and Polak, J. M. (1990). Development of neuroendocrine tumors in the gastrointestinal tract of transgenic mice. Heterogeneity of hormone expression. Am J Pathol 136(6): 1349-1363.

18. Sidhu, S. S., Thompson, D. G., Warhurst, G., Case, R. M. and Benson, R. S. (2000). Fatty acidinduced cholecystokinin secretion and changes in intracellular $\mathrm{Ca}^{2+}$ in two enteroendocrine cell lines, STC-1 and GLUTag. J Physiol 528 Pt 1: 165-176.

19. Spreckley, E. and Murphy, K. G. (2015). The L-Cell in nutritional sensing and the regulation of appetite. Front Nutr 2: 23.

20. Verhoeckx, K., Cotter, P., López-Expósito, I., Kleiveland, C., Lea, T., Mackie, A., Requena, T., Swiatecka, D. and Wichers, H. Eds (2015a). General Introduction. In: The Impact of Food Bioactives on Health: In Vitro and Ex Vivo Models VII-XIII. Springer.

21. Verhoeckx, K., Cotter, P., López-Expósito, I., Kleiveland, C., Lea, T., Mackie, A., Requena, T., Swiatecka, D. and Wichers, H. Eds (2015b). Part IV, Enteroendocrine Cell Models: General Introduction. In: The Impact of Food Bioactives on Health: In Vitro and Ex Vivo Models. Springer. 